\title{
AN ATTEMPT TO REDUCE THE EMISSION OF SPARK-IGNITION ENGINE WITH MIXTURES OF BIOETHANOL AND GASOLINE AS SUBSTITUTE FUELS
}

\author{
Wojciech Gis, Maciej Gis, Piotr Wiśniowski \\ Motor Transport Institute \\ Jagiellonska Street 80, 03-301 Warsaw, Poland \\ tel.: +4822 4385400, fax: +48224385401 \\ e-mail:maciej.gis@its.waw.pl \\ maciej.gis@its.waw.pl,piotr.wisniowski@its.waw.pl \\ Mateusz Bednarski \\ Warsaw University of Technology \\ Faculty of Automotive and Construction Machinery Engineering \\ Narbutta Street 84, 02-524 Warsaw, Poland \\ tel.: +4822 234 8517, fax: +48228490303 \\ e-mail:m.bednarski@simr.pw.edu.pl
}

\begin{abstract}
Limiting emissions of harmful substances is a key task for vehicle manufacturers. Excessive emissions have a negative impact not only on the environment, but also on human life. A significant problem is the emission of nitrogen oxides as well as solid particles, in particular those up to a diameter of 2.5 microns. Carbon dioxide emissions are also a problem. Therefore, work is underway on the use of alternative fuels to power the vehicle engines. The importance of alternative fuels applies to spark ignition engines.

The authors of the article have done simulation tests of the Renault K4M $1.616 \mathrm{v}$ traction engine for emissions for fuels with a volumetric concentration of bioethanol from 10 to 85 percent. The analysis was carried out for mixtures as substitute fuels - without doing any structural changes in the engine's crankshafts. Emission of carbon monoxide, carbon dioxide, hydrocarbons, oxygen at full throttle for selected rotational speeds as well as selected engine performance parameters such as maximum power, torque, hourly and unit fuel consumption were determined.

On the basis of the simulation tests performed, the reasonableness of using the tested alternative fuels was determined on the example of the drive unit without affecting its constructions, in terms of e.g. issue. Maximum power, torque, and fuel consumption have also been examined and compared. Thus, the impact of alternative fuels will be determined not only in terms of emissions, but also in terms of impact on the parameters of the power unit.
\end{abstract}

Keywords: simulation, combustion engines, air pollution, environmental protection

\section{Introduction}

According to the United Nations, around 55\% of world's population lives in urban areas. This percentage is to expand and by the year 2050 to reach the level of $68 \%$. Such a large inflow to cities means many challenges [1] of which one can mention, among others, growing problem of the increasing number of vehicles being purchased in Poland. According to [2], the number of vehicles in Poland for year 2017 was 29149 178. Comparing to 2007, it is 49.7\% more. However, the average age of vehicles in Poland is 12 years [3]. In addition, in 2018, over one million used vehicles were imported to Poland [4]. This is the reason for constantly worsening air quality in cities.

The NEC Directive imposed an obligation on Poland, which is to reduce, as compared to 2005, some of air pollution substances/air pollutants, including $\mathrm{PM}_{2.5}$ and $\mathrm{NO}_{\mathrm{x}}$. It includes that during the 
ten-year time perspective (2020-2029) emission reduction on a national scale will amount to $16 \%$ for $\mathrm{PM}_{2.5}$ and $30 \%$ for $\mathrm{NO}_{\mathrm{X}}$. The analysis in the period up to 2015 indicates that in relation to the reference year -2005 , the total emission of these substances was limited in both cases by $18 \%$. Thus, the current rate of reduction of nitrogen oxide emissions will be too low to reach the set ceiling for emission reduction of these substances. Therefore, it will be required to implement solutions that will effectively reduce $\mathrm{NO}_{\mathrm{x}}$ emissions, especially in the transport and communal-household sectors [5].

The problem is not only the emission of harmful substances, but also the emission of substances affecting the greenhouse effect. The main challenge for the world is to prevent a situation where the average temperature rises by 1.5 -Celsius degrees. This is one of the reasons, why the European Commission, on the 8th of November 2017, presented a proposal setting new standards for carbon dioxide emissions after 2020, for passenger cars and trucks up to 3.5 tones. The proposal also sets out incentives for the production of zero-emission and low-emission vehicles [6].

Therefore, it is advisable to use alternative fuels to power vehicle engines. It is important not only to implement modern technologies in new vehicles but it is also reasonable to rework older structures for supplying alternative fuels (for example fuel mixtures). Ethanol fuels can be an example of such use.

Commonly used for the production of ethanol fuels is anhydrous bioethanol, the quality of which is determined in Europe by the EN 15376 standard. According to [7], due to the amount of bioethanol in fuels for spark-ignition engines, we divide the fuels into:

- fuels with low bioethanol content (up to 10\%) - this class includes E10 motor gas as well as E5. It is available i.e. in the US, New Zealand, Australia and in European countries such as Finland, France and Germany. The requirements that must be met by this fuel are set out in EN $228+\mathrm{A} 1$,

- fuels with an average bioethanol content (20-25\%) - This is a gasoline designated E20, which is available primarily in Thailand, Paraguay and Brazil and its quality requirements are determined by national standards,

- fuels with a high content of bioethanol (up to 85\%) - Fuel marked with the symbol E85. It is available, among others, in the USA, Brazil, Germany, France, Sweden, Norway, the United Kingdom, the Netherlands, the Czech Republic, Hungary and Lithuania. The requirements that must be met by this fuel in Europe are defined in CEN / TS 15293.

In some countries, you can also find fuels that contain hydrated bioethanol. The quality of such fuel is determined by national specifications. For example, there is HE-15 gasoline in the Netherlands, which contains up to $15 \%$ of the hydrated bioethanol. In Brazil, however, there is a fuel marked with E100 symbol, which main ingredient is bioethanol containing 4.9\% water [8].

\section{Bioethanol}

Bioethanol is an ethyl alcohol, which is also used as a fuel for internal combustion engines. Due to the raw materials from which it is produced, we distinguish its 3 generations [3]. Bioethanol can be produced from sugar or cereal starch, which can be converted into alcohol during the fermentation process. Another material that can be used for this purpose is lignocellulose biomass from e.g. straw, wood, vegetable waste from the food industry and waste from paper production, while microalgae are used for the production of bioethanol of the third generation. The tasks currently posed by fuels include meeting emission standards and ensuring appropriate operational and operational properties. In 2009, the European Directives RED and FQD were introduced, which allowed an increase for bioethanol in gasoline to $10 \%$ by volume.

The properties of fuels with a high content of bioethanol in comparison to petrol specified in the PN-EN 228 standard, which may contain up to $10 \%$ of the volume of this alcohol, are significantly diversified, and their diversity increases with the increase in its share in fuel. Tab. 1 shows the most significant differences between petrol and bioethanol. 
Tab. 1. Comparison of physicochemical properties of gasoline and ethanol [9]

\begin{tabular}{|l|c|c|}
\hline \multicolumn{1}{|c|}{ The properties } & Petrol $(\mathrm{PN}-\mathrm{EN} 228)$ & Bioethanol \\
\hline Chemical formula & $\mathrm{mC}_{\mathrm{n}} \mathrm{H}_{2 \mathrm{n}}$ & $\mathrm{C}_{2} \mathrm{H}_{5}-\mathrm{OH}$ \\
\hline Density $\left[\mathrm{kg} / \mathrm{m}^{3}\right]$ & $720-775$ & 794 \\
\hline Molecular weight & 114,2 & 46 \\
\hline The calorific value $[\mathrm{MJ} / \mathrm{kg}]$ & $42.3-43.5$ & 26.8 \\
\hline Evaporation heat $[\mathrm{kJ} / \mathrm{kg}]$ & 350 & $855-870$ \\
\hline Research octane number & $95 \mathrm{~min}$ & $120-135$ \\
\hline Motor octane number & $85 \mathrm{~min}$ & $100-106$ \\
\hline Boiling point $\left[{ }^{\circ} \mathrm{C}\right]$ & $20-200$ & 77.8 \\
\hline Flash-point $\left[{ }^{\circ} \mathrm{C}\right]$ & -42 & 12.8 \\
\hline temperature of self-ignition $\left[{ }^{\circ} \mathrm{C}\right]$ & $300-450$ & 420 \\
\hline $\begin{array}{l}\text { Stoichiometric } \text { excess coefficient } \\
\text { The air is burning the mixture } \chi\end{array}$ & 14.7 & 9.0 \\
\hline
\end{tabular}

\section{Simulation model}

The model was built based on a real object - four-cylinder internal combustion engine with spark ignition and an indirect injection produced by Renault, designated K4M 616. It is a 16-valve engine with a capacity of 1598 [cm3]. Detailed technical data of this engine is presented in Tab. 2. Fig. 1 shows the Renault K4M 616 engine model created in the AVL BOOST program. This software is used to simulate the operation of internal combustion engines [10].

Tab. 2. Technical data of Renault K4M 616 engine

\begin{tabular}{|l|c|}
\hline Engine identification & K4M 616 \\
\hline Capacity of the engine & $1598\left[\mathrm{~cm}^{3}\right]$ \\
\hline Number of cylinders/valves & $4 / 16$ \\
\hline The degree of compression & $10: 1$ \\
\hline The diameter of the cylinder/piston stroke & $79.5 / 80.5[\mathrm{~mm}]$ \\
\hline Maximum power & $77[\mathrm{~kW}]$ \\
\hline Rotational speed of maximum power & $5750[\mathrm{rpm}]$ \\
\hline Maximum torque & $148[\mathrm{Nm}]$ \\
\hline Speed of maximum torque & $3750[\mathrm{rpm}]$ \\
\hline
\end{tabular}

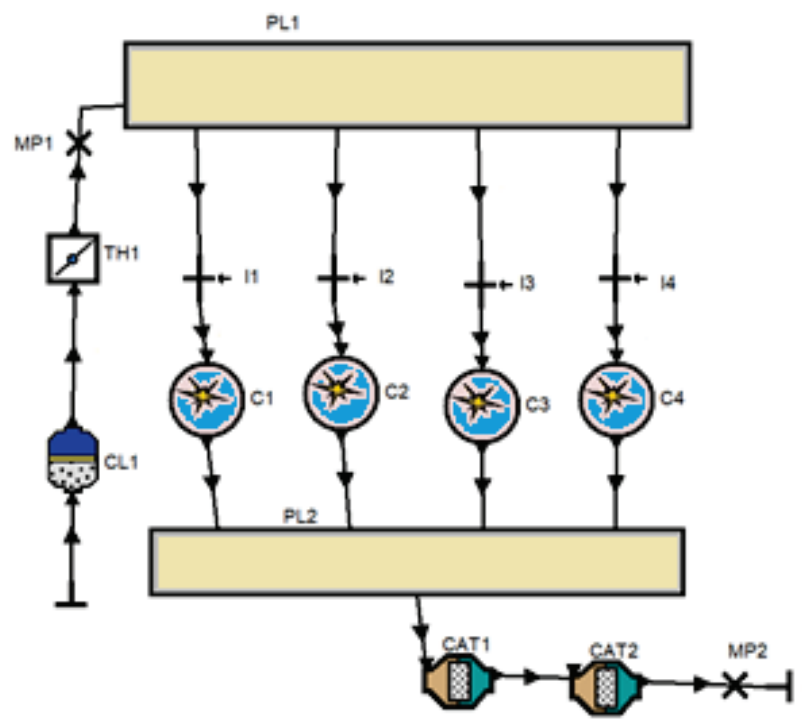

CL1 - air filter

TH1 - throttle

MP1 - measuring point 1

PL1 - intake manifold

I1, I2, I3, I4 - injectors

$\mathrm{C} 1, \mathrm{C} 2, \mathrm{C} 3, \mathrm{C} 4-$ cylinders

PL2 - exhaust manifold

CAT1, CAT2 - catalytic reactors

MP2 - measuring point 2

Fig. 1. Model of combustion engine in the AVL BOOST program 
The designed model was used i.e. to determine engine performance parameters such as power, torque, along with specific and hourly fuel consumption. During the simulation, the emission levels of harmful exhaust components such as carbon monoxide (CO), hydrocarbons ( $\mathrm{HC})$ and nitrogen oxides $(\mathrm{NO})$ as well as the oxygen content $\left(\mathrm{O}_{2}\right)$ in the exhaust gases were also examined. All simulations of the engine working with different fuels were carried out at the same ignition timing for individual rotational speeds in the range from 1000 to 6000 [rpm].

\section{Results after the simulation}

Registered results made it possible to compare the performance parameters of Renault K4M 616 engine with conventional fuel and a fuel-alcohol mixture. Fig. 2 presents the comparison of effective power generated by an internal combustion engine when supplied with petrol (E5) and mixtures such as E10, E20, E30, E50 and E85.

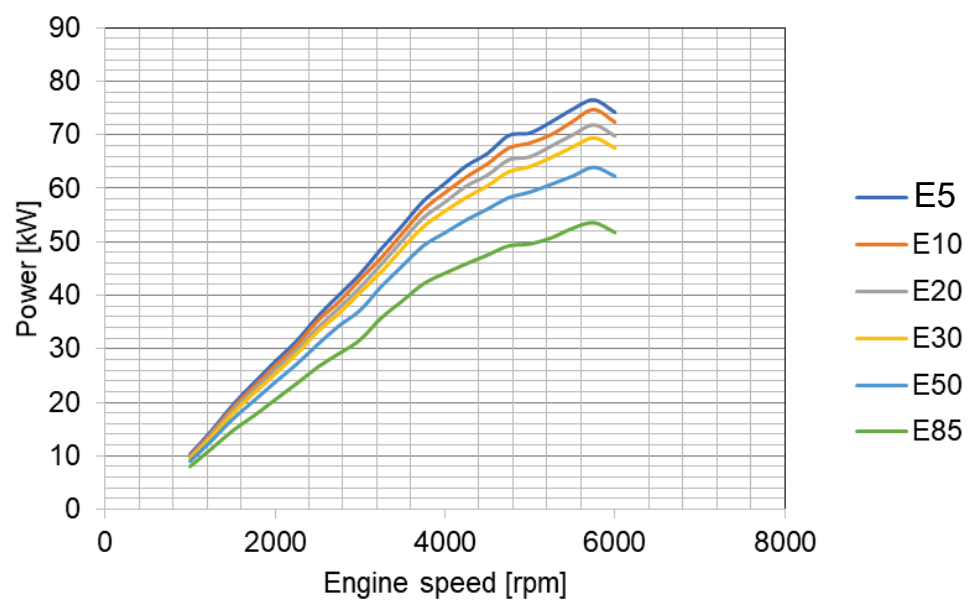

Fig. 2. The effective power of the spark-ignition engine, powered by various fuels at full throttle

It is visible on the diagram, that the power generated by this engine reaches maximum value of approximately $77[\mathrm{~kW}]$ for the rotational speed of 5750 [rpm] when supplied with petrol, which proves that the created model is in good agreement with the actual object. As the content of bioethanol in the fuel and alcohol mixture increases, the power decreases in the entire engine speed range. If alcohol concentration in the fuel mixture reaches more than $30 \%$ of its volume, a decrease in engine power can be observed. For example, the difference in maximum power between the supply of E50 and E85 and conventional gasoline is 12 and $22[\mathrm{~kW}]$, respectively. For E30 fuel compared to petrol, the difference is $7[\mathrm{~kW}]$, for E20 about $5[\mathrm{~kW}]$ and the lowest for fuel supply $\mathrm{E} 10-2[\mathrm{~kW}]$.

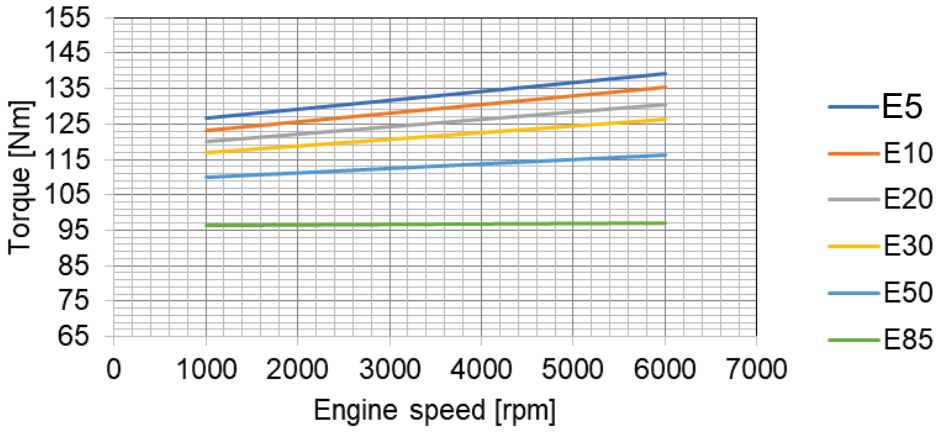

Fig. 3. Torque generated by a spark-ignition engine, powered by various fuels at full throttle 
According to the manufacturer's data, this engine should develop a maximum torque of approximately $147[\mathrm{Nm}]$ at 3750 [rpm] when fuelled with petrol. Similarly, as with the power, increasing bio-alcohol content in the fuel causes reduction of the torque value, generated by the combustion engine in the whole range of its rotational speed. This happens when the engine is not adapted to supply a fuel mixture containing alcohol. For example, the use of E85 fuel to power the engine results in a decrease of the maximum torque value to 39 [Nm]. A much better result can be obtained using E50 fuel, where the difference compared to gasoline is 23 [Nm]. For fuels E10, E20 and E30, the decrease in this parameter is 4,8 and $12[\mathrm{Nm}]$, respectively.

With the higher content of the bioethanol, fuel consumption in the whole engine speed range increases, which is caused by the significantly lower calorific value of bioethanol. For an alcohol content less than $30 \%$ of the fuel's volume, this increase is maximum 8\%, while for E50 and E85 fuels the increase of this parameter is $15.5 \%$ and $34 \%$ respectively.

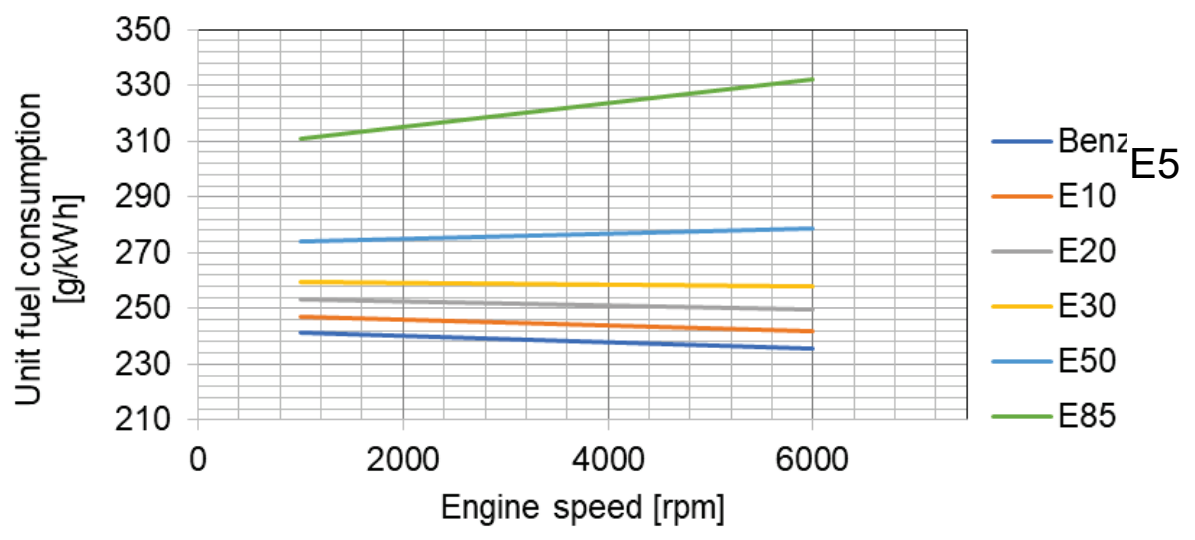

Fig. 4. Influence of the bio alcohol content in the fuel-alcohol mixture on the hourly fuel consumption by the engine at full throttle

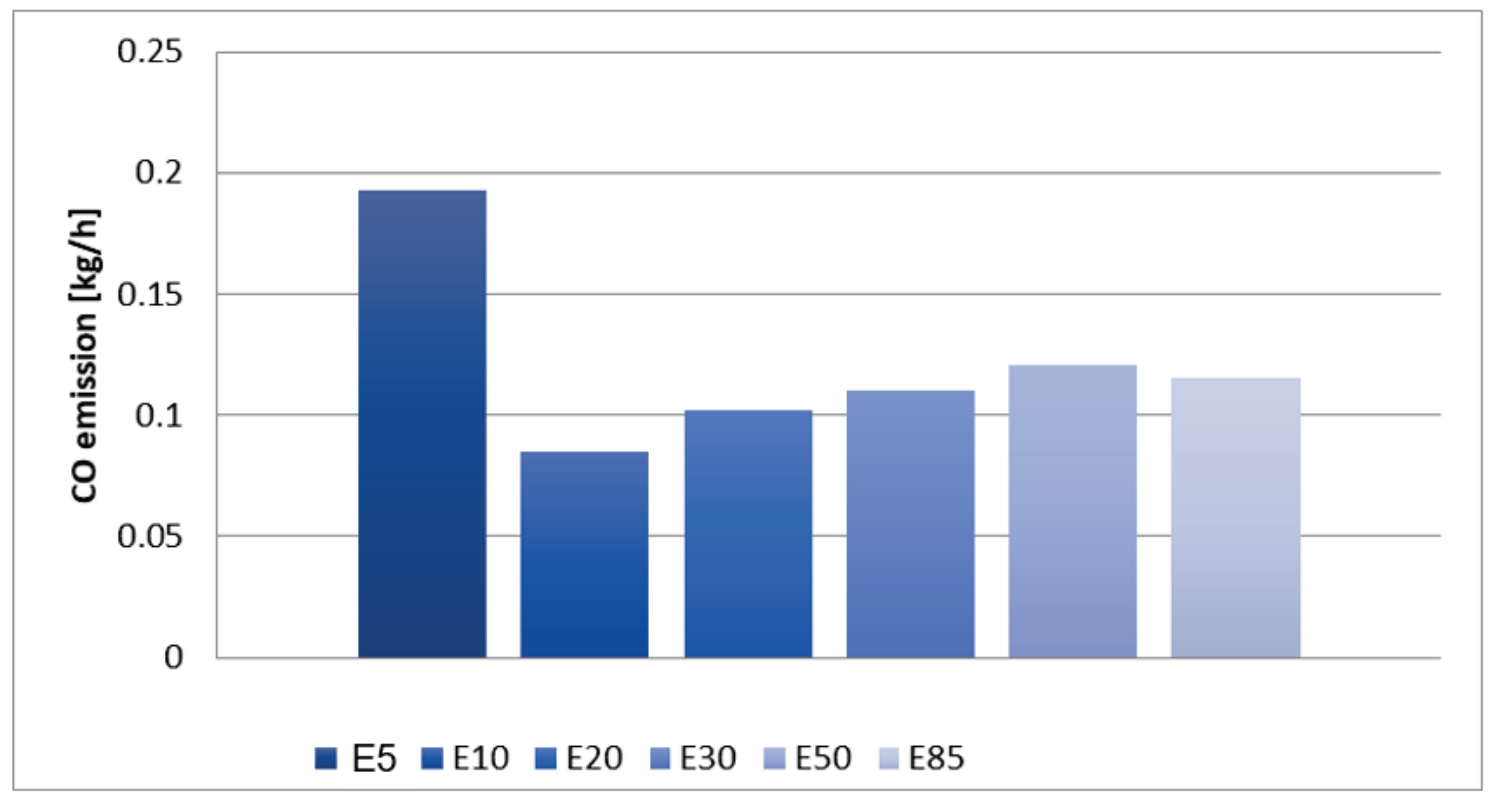

Fig. 5. CO emission for engine speed $3750 \mathrm{rpm}$

Carbon emission for fuel-alcohol mixtures is lower than in the case of gasoline. One of the reasons for this phenomenon is a lower temperature in the combustion chamber, which results from its better cooling during the intake stroke due to the higher heat of bioethanol evaporation. Another factor that may affect the reduced carbon monoxide emission is the relevantly lower carbon content 
in the bio alcohol, compared to conventional gasoline. Bioethanol contains oxygen, so the more alcohol in the mixture, the lower the need for additional oxygen in the fuel mixture. Software of the controller does not allow distinguishing the type of fuel used; therefore, the factor $\lambda$ is maintained at 14.7. The best result was obtained with the use of E10 fuel, while a further increase in the concentration of bioethanol in the mixture causes a worsening of the combustion process, thereby increasing the emission of carbon monoxide. When powering the engine with fuels containing alcohol, the emission of carbon monoxide is much lower than when powering it with gasoline. On the other hand, when speaking of E10, E20 and E30 fuels, the amount of carbon monoxide in the exhaust gas decreases with the increase of the rotational speed. However, for E50 and E85 at 3750 [rpm], the emission is lower than in the case of 2250 [rpm].

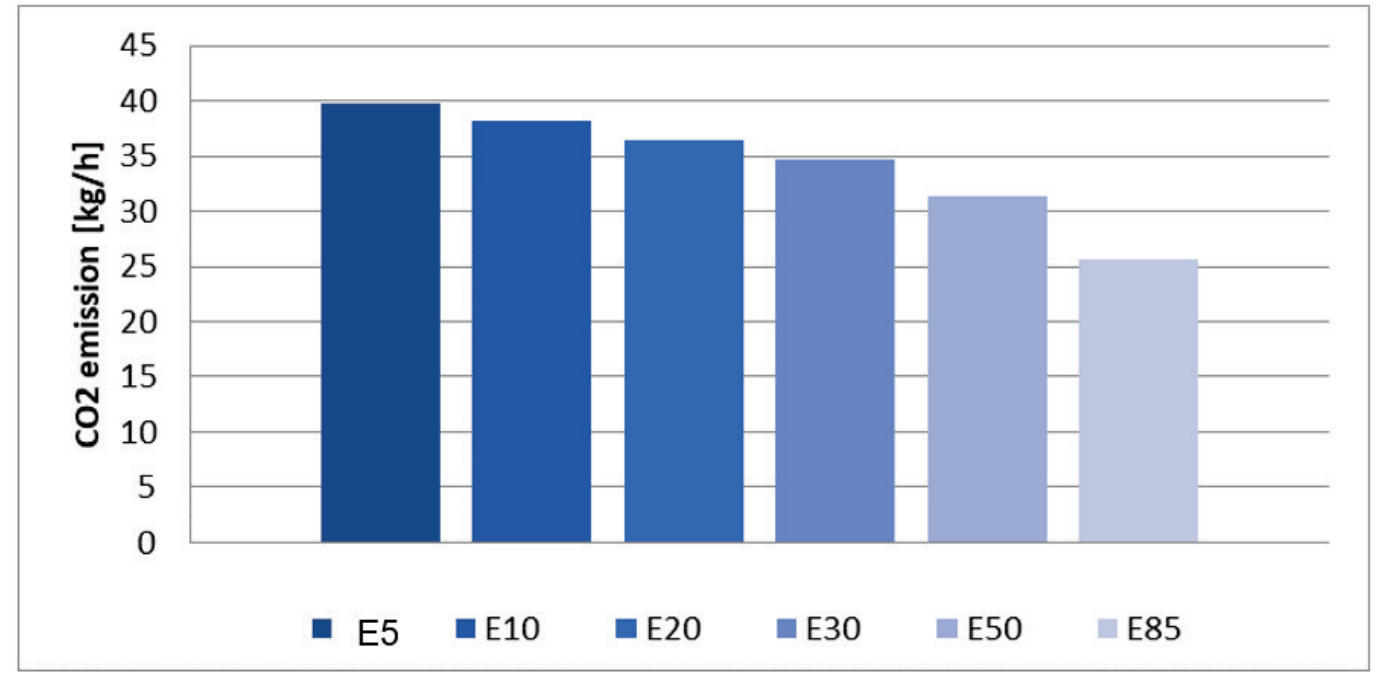

Fig. 6. $\mathrm{CO}_{2}$ emission for engine speed $3750 \mathrm{rpm}$

The amounts of emitted $\mathrm{CO}_{2}$ are similar at different rotational speeds within powering with one fuel. The increase in engine speed causes a slight reduction for carbon dioxide emissions in the exhaust gases. This may be due to the less precise combustion of the mixture and the increased emission of carbon monoxide. The decrease in emissions of this exhaust component may result from the much lower carbon content in bioethanol compared to conventional gasoline.

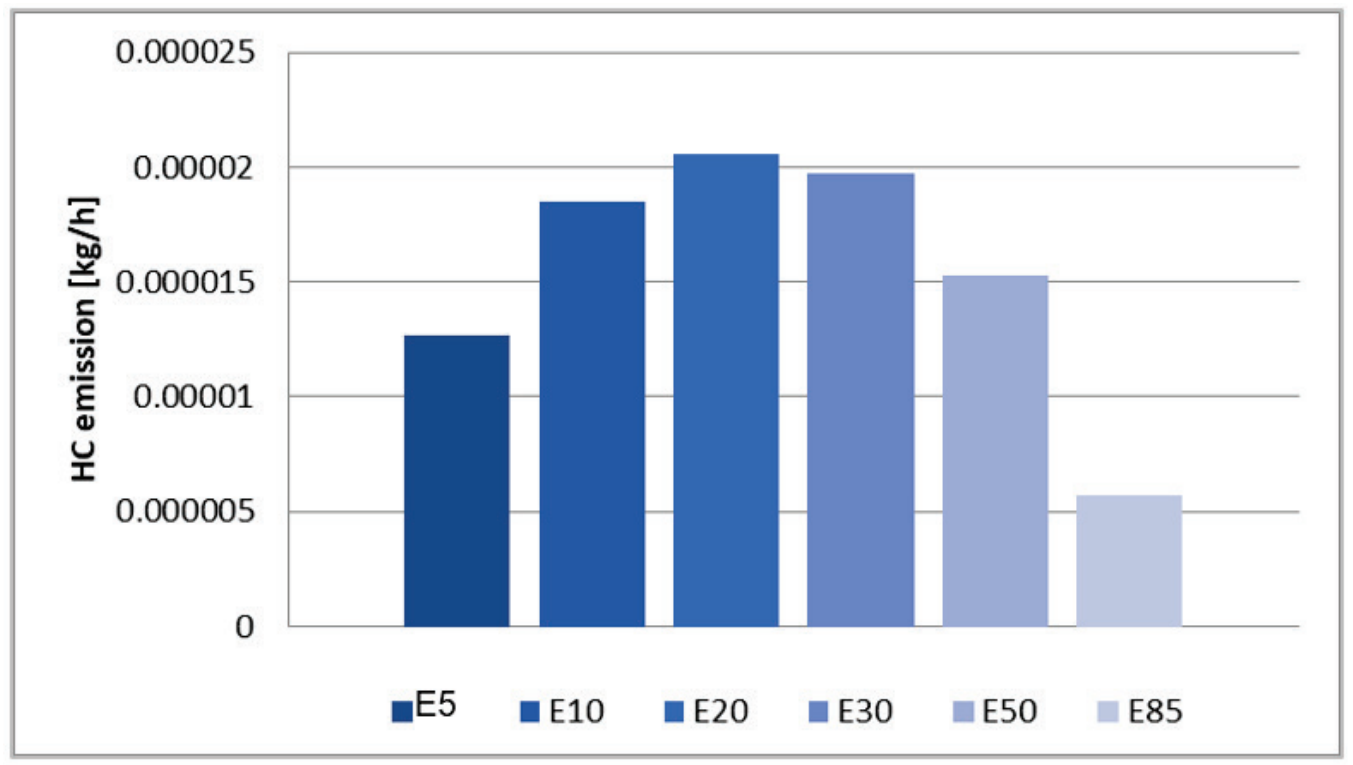

Fig. 7. HC emission for engine speed $3750 \mathrm{rpm}$ 
Bioethanol contains less hydrogen than conventional fuel. The addition of this alcohol in small quantities (up to 30\%) contributes to reducing the temperature in the combustion chamber, which makes the fuel combustion process worse than in the case of working with conventional fuel and results in a higher $\mathrm{HC}$ emission. However, at a ratio above $50 \%$, due to the lower content of carbon and hydrogen in the fuel and alcohol mixture, the hydrocarbon emission decreases. In the case of E85 fuel, it reaches much lower value than with engine powered by conventional fuel. For all fuels, the increase in rotational speed contributes to increasing the $\mathrm{HC}$ content in the exhaust, which may be caused by the increasingly shorter duration of the combustion process of the air-fuel mixture. For fuel-alcohol mixtures with a concentration of bioethanol lower than $50 \%$ of the mixture's volume, the emission value of this component is higher than in the case of gasoline. Only the use of E85 fuel contributes to the reduction of hydrocarbon emissions to the atmosphere.

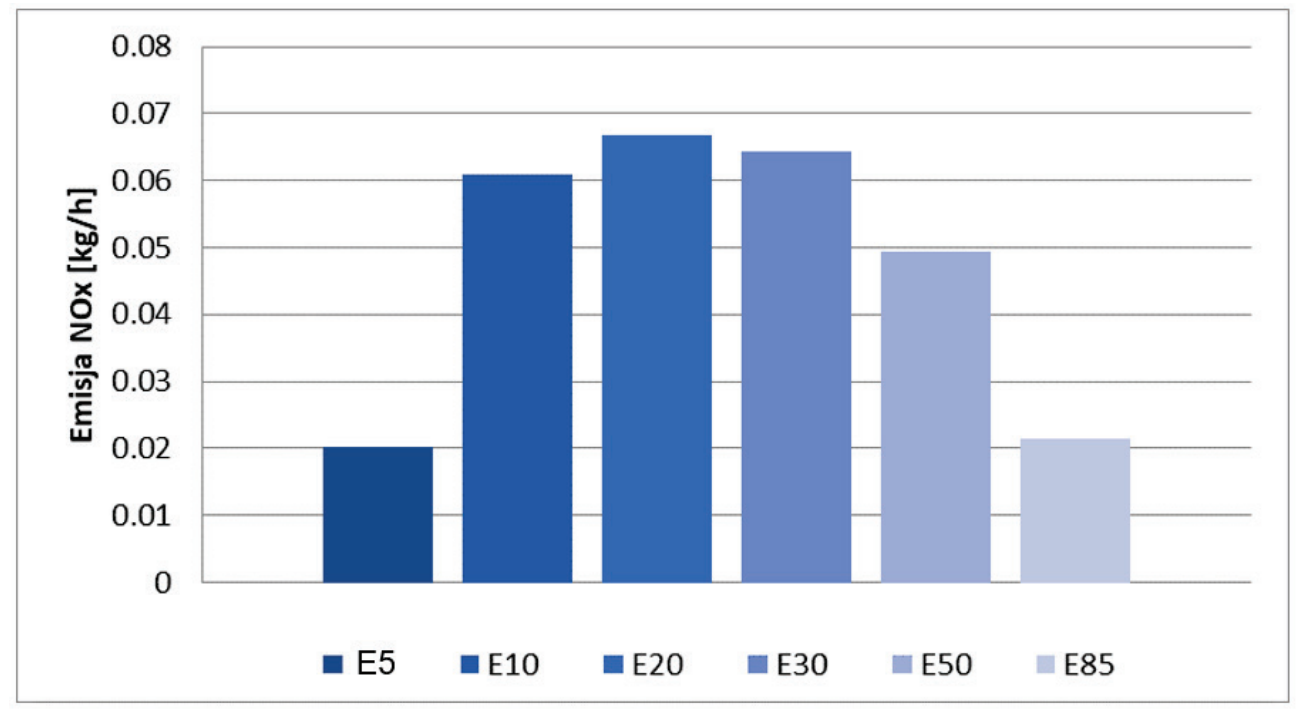

Fig. 8. $N O_{X}$ emission for engine speed $3750 \mathrm{rpm}$

In vehicles unsuitable for fuel-alcohol mixtures, the controller's algorithm does not allow distinguishing the type of fuel, making it impossible to select the appropriate settings such as, for example, advanced ignition timing, fuel dose or excess air ratio/air-fuel ratio. As a result, the use of bio-alcohol as an additive to conventional gasoline may be the cause of engine running on a lean mixture, which in turn will contribute to a significant increase in emission of nitrogen oxides. Only the concentration of bioethanol greater than $30 \%$ of the fuel volume reduces NOX emission due to the high value of the heat of evaporation, which again translates into a decrease of the temperature prevailing in the combustion chamber. Only the use of E85 fuel contributes to reducing the combustion temperature of the mixture to such a level, that the emission of nitrogen oxides is lower than in a comparison with conventional gasoline. As a result of higher engine speed, it may be observed that the temperature in the combustion chamber raises, which yields into higher emission of nitrogen oxides when using all tested fuels. The highest emission increase was recorded for the values of rotational speeds in the range of 2250-3750 [rpm].

\section{Conclusions}

Based on the calculations made, it can be concluded that:

- an engine that has not been adapted to supply fuel and alcohol mixtures is able to work properly on them. However, the decrease in power and torque generated by the engine during full throttle operation is noticeable,

- it is possible to use the fuel mixtures described in the article for various engines. In the case of units with worse power and torque parameters, the use of E10 and E20 fuel can be considered, 
in which bioethanol accounts for 10 and $20 \%$ of the fuel mixture respectively, and the use of which gives maximum power losses of 2.4\% (1.8 kW) for E10 and $6 \%(4.6 \mathrm{~kW})$ for E20. In the case of torque, these losses amount to a maximum of $2.8 \%(4.1 \mathrm{Nm})$ for E10 and $5.4 \%(7 \mathrm{Nm})$ for E20,

- analysing the properties of bioethanol, it can be concluded that the use of fuels containing the addition of this alcohol in vehicles that were not factory-adjusted to this source of power both in terms of steering, sensors and construction, and materials used to produce fuel system components or engine may be the cause of faults and exploitation problems,

- the use of bioethanol as an additive to conventional gasoline allows for a significant reduction of carbon monoxide emissions compared to emissions during operation of the engine on traditional fuel. The best effect was obtained for E10 fuel, which is a mixture containing $10 \%$ of bio-alcohol and $90 \%$ of gasoline (E5), the worst for E50. The use of other mixtures allows to reduce the emission of toxic substances in the exhaust system,

- the higher the bio-alcohol content in the fuel mixture, the lower the $\mathrm{CO}_{2}$ emission. For this reason, the use of E85 fuel allows to reduce the emission of this component by $34.3 \%$ for low and medium rotational speeds,

- in the case of hydrocarbons, the addition of bio alcohol to conventional gasoline results in a significant increase in emissions of up to $100 \%$ for E20 at 2250 [rpm]. The exception is E85 fuel, for which there is a clear reduction in the amount of $\mathrm{HC}$ in the exhaust, which reaches even $54.1 \%$ at 3750 [rpm],

- for E10, E20 and E30 fuels, an increase in the content of nitrogen oxides in the exhaust gas of an average of $200 \%$ was observed. The cause could be the presence of oxygen in the chemical structure of bioethanol. The only substitute for conventional gasoline could be E85 fuel, where it was possible to observe a lower emission of $26 \%$ at 2250 [rpm], when used at low and high engine speeds.

\section{References}

[1] DataArt, Transport-sharing w Polsce, Report, January 2019.

[2] https://stat.gov.pl/.

[3] https://www.samar.pl/.

[4] Gis, M., Wyniki sprzedaży aut w roku 2018, Menadżer Floty, Warszawa 2019.

[5] NIK, Ochrona powietrza przez zanieczyszczeniami, Warszawa 2018.

[6] Gis, M., Unia Europejska przycina emisję CO2, Pociagnie to za soba niższe zużycie paliwa, (http://moto.pl/MotoPL/7,88389,23277145, unia-europejska-przycina-emisje-co2-pociagnieto-za-soba-nizsze.html), Warszawa 2018.

[7] Pałuchowska, M., Formuły paliw etanolowych - wplyw na wtaściwości eksploatacyjne, NaftaGaz, Nr 9, 2017.

[8] Owczuk, M., Matuszewska, A., Odziemkowska, M., Bednarski, M., Wojs, M.K., Lasocki, J., Evaluation of the impact of the hydration degree of bioethanol on the operation parameters of the spark-ignition engine, Combustion Engines, 1(2(169)/2017), pp. 71-75, 2017.

[9] Żółty, M., Stępień, Z., Paliwa etanolowe w zastosowaniu do silników o zapłonie iskrowym, Nafta-Gaz, Nr 9, 2016.

[10] Orliński, P., Bednarski, M., Sikora, M., Simulation studies and empirical research of particulate matter's emission in diesel engine powered by liquid alternative fuels, Zeszyty Naukowe Instytutu Pojazdów, 1/2(111)/2017, 2017.

Manuscript received 24 June 2019; approved for printing 26 September 2019 